\title{
Effect of Sakura Block on Milk Production and Milk Quality of FH Cows in Late Lactation
}

\author{
Jarmuji, D. Suherman, Yanuri, R. Afriansyah, and E. Sulistyowati \\ Department of Animal Husbandry, Faculty of Agriculture, University of Bengkulu \\ Jl. WR. Supratman, Kandang Limun, Bengkulu \\ Corresponding Author: esulistyowati@unib.ac.id
}

\begin{abstract}
This study aims to evaluate milk production, fat content, and protein content of Friesian Holland (FH) dairy cow's milk by giving Sakura block at the final lactation of FH cow. The design usedwas the Latin Square Design (LSD), with treatments of P0 (0 Sakura blocks), P1 (300 gr Sakura blocks), P2 (600 gr Sakura blocks), and P3 (900 gr Sakura blocks). This study involved four dairy cows for four periods of which period consisted of 10 treatment days, where the last 3 days of each period were the milk sample collection. Milk production and feed consumption were measured and weighed daily. The results showed that the treatment had a significant effect $(\mathrm{P}<0.05)$ on the consumption of dry matter ratio and no significant effect $(\mathrm{P}>0.05)$ on milk production, fat content, and milk protein.
\end{abstract}

Key words: Sakura block, dry matter intake, milk production, fat, protein, late FH lactation cow

\section{INTRODUCTION}

Availability of feed of dairy cows is influenced by the potential that exists in the environment and the season that is underway. The quantity and quality of forage, concentrates, and supplements given to the dairy cows determine the production and quality of milk. Modification of nutrients such as the provision of Supplements Sakura block as a modification of the formula UMMB (Urea Multinutrient Mineral Block) by substituting molasses using palm sugar.

Modification of the formula UMMB by using brown sugar as a substitute, molasses is expected to increase weight gain and feed efficiency in goat. Modification of UMMB by Santoso (1999) named Sakura blocks (Sago Urea Aren Mineral Block). The results of the research showed that the use of the Sakura blocks on the goat beans increased the average consumption of dry materials, organic materials, water consumption, body weight gain, and feed efficiency (Jarmuji, 2000). Sakura block as a feed supplement is expected to function as a carbohydrate easily dissolved, protein escapes degradation and as a source of glucose in the formation of the raw material for the production of milk. It was also reported that the addition of $\mathrm{UMB}$ in the feed of dairy cows that are lactating can increase the milk by $3.60 \%$ (Yusran et al., 1988).

Other supplement is the Tabut block Madura lactating cow got the Tabut block as much as $300 \mathrm{~g} / \mathrm{block} / \mathrm{cow}$ produced milk as much as $0.76 \mathrm{~kg} / \mathrm{head} / \mathrm{day}$, while the control cow produced only half or $0.38 \mathrm{~kg} / \mathrm{head} / \mathrm{day}$. This means an increase in production of $100 \%$ with supplementation Tabut Blocks (Sulistyowati et al., 2001). Then, the Tabut Block with the modified level solution of curcuma and fermented cassava as well as the size of the block has been applied to the FH cow, the result showed an increase in milk production as much as 2.81 $\mathrm{kg} / \mathrm{head} / \mathrm{day}$ (Sulistyowati et al., 2008). Sulistyowati and Edward (2009), stated that with the giving Tabut Block the of more than 0 to 450 $\mathrm{g}$ in cattle FH lactation yield of milk production increased from about $7.04 \mathrm{~kg} / \mathrm{head} / \mathrm{day}$ to 9.38 $\mathrm{kg} / \mathrm{h}$ ead/day or equalled to $24.89 \%$.

Based on some results of the research above, study of feeding Sakura block with some sizes were implemented. nutrients is expected by giving a Sakura block with an increased size will affect the production andquality of milk of dairy cows FH at late phase of lactation

\section{MATERIALS AND METHODS}

This research was carried out for 40 days in the Village of Suka Sari Kecamatan Kabawetan District Kepahiyang. The tool used in this study is a feed, drinking places, individual enclosure, balance, Sakura blocks, , stove, frying pan, analytical scales, measuring cups, books, and pens. The materials in this study were 4 cows Fries Holland (FH) that are lactating at 6-7 months of lactation, the ingredients of Sakura block (milled corn, urea, brown sugar, top mix, rice bran, starch, mineral mix, salt, and TSP).

This research was conducted with several stages starting with the preparation of the feed 
ingredients, preparation of the cage, preparation of livestock, implementation of treatment, the analysis of laboratory and data. The preparation of feed ingredients and the manufacture of Sakura blocks based on the formula below.

Table 1. The formula of Sakura block

\begin{tabular}{lc}
\hline \multicolumn{1}{c}{ Ingredients } & $\begin{array}{c}\text { Formula } \\
(\%)\end{array}$ \\
\hline Brown sugar & 32 \\
Rice bran & 28 \\
Corn & 15 \\
Sago & 15 \\
Urea & 5 \\
TSP & 1 \\
Salt & 2 \\
Mineral Mix & 1 \\
Top Mix & 1 \\
\hline Total & 100 \\
\hline
\end{tabular}

The procedures of making Sakura's block were:

- All ingredients were weighed, brown sugar melted with $200 \mathrm{ml}$ of water in a saucepan, heated above the flame.

- Red Sugar liquid mixed with all other ingredients in a large container until evenly distributed.

- A mixture of materials was weighed of 300 gr/ block.

- Sakura block was wrapped in plastic.

Cage that is available in the farm, and equipped with an feed and drinking places. The floor and the roof are made of zinc with an open vent. The livestock used for the study were ascertained to be in a healthy condition and lactation at the end phase.

The feed is given in the form of forage consisting of grass that is usually given by the breeder. Fresh Forage given as much as $10 \%$ of body weight of cattle and Sakura Block treatment. Additional feed was consumed by livestock directly. Additional feed was given in the morning with the amount depended on each treatment. The provision of drinking water to the cattle given $a d$ libitum, drinking water should always be available in a cage and in a sufficient amount. To ensure the feed consumption optimally.

Treatment Sakura blocks given were :

P0 : Control/no Sakura block

P1 : Treatment given 1 block or 300 gr Sakura block

P2 : Treatment given 2 blocks or 600 gr Sakura block

P3 : Treatment given 3 blocks or 900 gr Sakura block

The variables measured were consumption of the dry matter conducted in each milking in the morning and afternoon by calculating the difference of feed given and the remainder is multiplied by the content of dry material. Milk production weighed on the milking in the morning and evening every day. The quality of the milk protein in the composite on milking the last 3 days of each period.

Draft of research and data analysis using the Design of Latin Square by using 4-treatments, 4-periods, and 4 heads of cattle, which was one period during the 10-day, 3-day transition period and 7 days of collection. Data analysis using Anova and if there were significant difference continued with Duncan Multiple Range Test (DMRT) according to Lentner and Bishop (1986).

\section{RESULTS AND DISCUSSION}

\section{Stage of Dairy Cow in Lactation}

Four dairy cows were used in this study are described in Table 2 . The body weight of four dairy cows used relatively the same, about $500 \mathrm{~kg} / \mathrm{h}$ ead. The status of lactation mirrored with the age of gestation of about 6.5 months, which means almost entered the dry period.

Table 2. Stage of the dairy cows used

\begin{tabular}{ccc}
\hline Cow & Body weight $(\mathrm{kg})$ & Gestation (months) \\
\hline A & 500.1 & 7 \\
B & 499.5 & 6 \\
C & 499.8 & 7 \\
D & 500.4 & 6 \\
Average \pm std & $499.95 \pm 0.39$ & $6.5 \pm 0.58$ \\
\hline
\end{tabular}




\section{Consumption of Ration Dry Matter}

Consumption of dry matter ration of $\mathrm{FH}$ in late lactation given supplement Sakura Blocks on each treatmentcan be seen in Table 3 below.

Based on Table 3 analysis of variance showed that the consumption of DM ration of $\mathrm{FH}$ given Sakura Block were significant differences $(\mathrm{P}<0.05)$. The average consumption of dry matter of $\mathrm{P} 2$ and $\mathrm{P} 3$ were $10.68 \mathrm{~kg} / \mathrm{head} / \mathrm{day}$ and 10.71 $\mathrm{kg} / \mathrm{h}$ ead/day higher than P0 and P1 as much as $10.01 \mathrm{~kg} / \mathrm{head} /$ day and $10.25 \mathrm{~kg} / \mathrm{head} /$ day. This difference occurs because of the supplementation of Sakura Blocks with different levels in each treatment. Consumption of dry matter was the highest in P3 treatment because the treatment of such provision of Sakura Block of the highest that as much as $900 \mathrm{~g}$. From the calculation, it is known that the ratio between the consumption of the dry matter of Sakura Block with the consumption of dry forage in a row of $2.61 ; 5.22$; and of $7.96 \%$, respectively in $\mathrm{P} 1, \mathrm{P} 2$, and $\mathrm{P} 3$.
Consumption in this study was low compared with the consumption of DM ration of the block with curcuma and fermented cassava, ranging 16.64 - $1733 \mathrm{~kg} / \mathrm{head}$ (Sulistyowati et al., 2008). From the calculation of the needs of the dry matter for $4 \%$ FCM milk production, $10 \mathrm{~kg}$ with dairy cow weight of $500 \mathrm{~kg}$ is $2.4 \%$ of body weight, which is $12 \mathrm{~kg}$ according to NRC (1989). Meanwhile, from the data consumption, DM ration in this study amounted to 10.01 to 10.71 $\mathrm{kg} / \mathrm{h}$ ead/day, so we can say the right needs of the dry matter have not met the needs of the dry matter dairy cows were used. However, milk production in this study only approximately $1.27-1.39$ $\mathrm{kg} / \mathrm{h}$ ead/day (Table 4). So, supposedly, the consumption of dry ration is more than enough for the level of milk production of it. However, the nutritional needs for pregnancy also need to be taken into account because the cow used was pregnant of about 6.5 months. Requirement of dry ration will be greater.

Table 3. Average of consumption of dry matter (DM) ration with Sakura blocks in dairy cattle

Variable
Consumption of forage
DM (kg/head/day)
Consumption of DM
Sakura block
(kg/head/day)
Consumption of DM
Ration (kg/head/day)
Description : P0 = (without Sakura block), P1 = (Sakura
block 900 gr) shows significant difference
$\quad$ Mukhtar (2006) explains that two factors
affect the production and composition of milk,
namely genetic and environmental. In Table 5 , it
can be seen that the consumption of DM cattle
rations has been fulfilled, then it can be said that
the low milk production in this study is not a result
of a lack of feed. Low milk production is
influenced by the state of the livestock at the time
of research is being pregnant, cow A and C are
pregnant ranges between $6-7$ months and cow B
and D in the state of pregnant is approximately 6
months. Consumption of dry material is widely
used for the growth of the fetus and the
preparation of the birth, not only for the
production of milk, so milk production is low.

\section{Production and Efficiency of Milk}

The production and quality of milk of cow's FH at the end phase of lactation of a given Sakura Block supplement on this can be seen in Tabel 4 . In the table 4 based on the analysis of variance can be seen that the production of milk given Sakura Block did not have an effect $(\mathrm{P}>0.05)$ or non-significant, ranged from 1.27 to $-1.39 \mathrm{~kg} / \mathrm{head} / \mathrm{day}$. This is different from earlier research results reported by Sulistyowati and Edward (2009) that feeding of Tabut Block more than 0 up to 450 gram resulted in production of milk increased from about 7.04 $\mathrm{kg} / \mathrm{head} / \mathrm{day}$ to $9.38 \mathrm{~kg} / \mathrm{head} /$ day or by $24.89 \%$. The low production of milk is because the phase of lactation was almost at the end. The results of this study are also still much lower than the average milk production of FH cows in Indonesia. Sudono et al. (2003) stated that the general productivity of cows of FH in Indonesia is low, where an average milk productionis 10.28 $\mathrm{kg} / \mathrm{h}$ ead/day or less $3.050 \mathrm{~kg} /$ lactation. 
Table 4. Average milk production and consumption of drinking water of FH cows that were given Sakura block

\begin{tabular}{lcccc}
\hline \multirow{2}{*}{ Variables } & \multicolumn{4}{c}{ Treatment } \\
\cline { 2 - 5 } & $\mathrm{P} 0$ & $\mathrm{P} 1$ & $\mathrm{P} 2$ & $\mathrm{P} 3$ \\
\hline $\begin{array}{l}\text { Milk production } \\
\text { (kg/head/day) }\end{array}$ & 1.34 & 1.27 & 1.39 & 1.39 \\
$\begin{array}{l}\text { Efficiency of milk } \\
\text { production }\end{array}$ & 0.133 & 0.124 & 0.130 & 0.129 \\
$\begin{array}{l}\text { Drinking wate } \\
\text { consumption } \\
(\mathrm{l} / \mathrm{head} / \text { day) }\end{array}$ & 15.1 & 13.2 & 13.1 & 15.7 \\
\hline
\end{tabular}

Description : P0 = (without Sakura blocks), P1 = (Sakura block 300 gr $), \mathrm{P} 2=($ Sakura block 600 gr $), \mathrm{P} 3=($ Sakura block $900 \mathrm{gr})$, the average among treatments were not significantly different not different $(\mathrm{P}>0,05)$

The production of $\mathrm{FH}$ milk can be affected by several factors as stated by Sudono et al. (2003). The factors affecting milk production of dairy cows include age of the pregnancy, period of lactation, large cow, age cow, and feeding. Cows that are genetically good production ability is not necessarily able to produce well, so did the opposite. The environment is good, good maintenance can not be guaranteed, when the breeds of dairy cows are reared has a genetic quality that is low.

The decrease in milk production during the end of the fourth month after lambing will be faster than the previous months (Molento, 2008 and Nugroho et al., 2010). Other factors which may cause low milk production that is genetic or hereditary. The decline in production due to the production phase itself will naturally decrease with the addition of a month of lactation. Milk production is also influenced by the period of lactation. Milk production in the period of lactation of the first more than the period of lactation next (Dewayani, 2012).

The efficiency of milk production is the ratio between milk production and consumption of dry ingredients. In this study, the level of efficiency of milk production is very low, $0.124-$ 0.130 . That is, only produced milk by $0.124-$ $0.130 / \mathrm{kg}$ DM consumed or $12.4-13.0 \%$. The efficiency of milk production is high on the provision of concentrate contains the skin of the durian fermentation in dairy cattle that ranged from $0.63-0.81$, are or $63-81 \%$, reported by Sulistyowati et al. (2018).

In Table 4, water consumption is between $13.1-15.7 \mathrm{l} / \mathrm{head} /$ day. This is lower according to Sudono et al. (2003) which states that the drinking water requirement of dairy cows is $10 \%$ of body weight, or about $50 \mathrm{~kg} / \mathrm{head} / \mathrm{day}$. The feed given is fresh elephant grass which contains a lot of water, so it can be said that water consumption in this study has met the needs of livestock. Environmental conditions at the time of the study had high rainfall, and daily temperatures that did not cause heat stress, thus causing less water consumption. Water consumption in livestock goes hand in hand with the amount of milk produced. Low water consumption means low milk production and vice versa if milk production increases then water consumption also increases.

Water consumption in livestock is strongly influenced by several factors including environmental factors, food conditions, physiological conditions, environmental temperature and genetics (Devendra and Burns, 1994). According to Sudono et al. (2003). Dairy cows need 4 liters of drinking water every day for every 1 liter of milk produced. This amount depends on the milk produced, the ambient temperature, and the type of feed given.

\section{Quality of Milk}

The data on the fat content and protein content of FH milk during this study can be seen in Table 5 below.

Based on the analysis of variance (ANOVA) there were no significantly different results $(\mathrm{P}>0.05)$ on the fat content and protein content of milk. The fat content and protein content of milk was influenced by the forage feed given and the condition of the cows during the study.The lactation period is the period when a cow is producing milk after giving birth, which is \pm 10 months between the time of calving and the dry period. Milk production per day begins to decline after two months of lactation. 
Table 5. Average fat and protein contents of lactating dairy cow's milk fed with Sakura block

\begin{tabular}{ccccc}
\hline \multirow{2}{*}{ Variable } & \multicolumn{5}{c}{ Treatment } \\
\cline { 2 - 5 } & P0 & P1 & P2 & P3 \\
\hline Fat $(\%)$ & 4.74 & 4.67 & 3.93 & 4.14 \\
Protein (\%) & 4.91 & 4.35 & 4.45 & 5.12 \\
\hline
\end{tabular}

Description : P0 = (without Sakura blocks), P1 = (Sakura block 300 gr $),$ P2 $=($ Sakura block 600 gr $)$, P3 $=($ Sakura block 900 gr), averages among treatments were not significantly different $(\mathrm{P}>0.05)$

This decrease was also followed by changes in the composition of milk, including milk fat content began to decrease after 1-2 months of lactation, then at 2-3 months of lactation, milk fat content began to be constant, then slightly increased (Sudono, 2003).

The condition of the cows used during the study were FH cows that had entered the end of lactation, so the possibility of an increase in fat content and milk protein content was affected. The decline in production in the seventh to eighth month was due to the cows being pregnant again. Milk production is inversely proportional to the percentage of protein and fat produced. According to Ensminger and Howard (2006), total milk production generally increases in the first month after delivery and decreases gradually, whereas fat content increases towards the end of lactation.

However, the fat content and protein content of milk meets the milk quality standards listed in the government regulation of the 2011 National Standardization Agency (SNI), which is a minimum of $3.00 \%$ milk fat content and $2.8 \%$ milk protein content. The highest yield of fat content was in treatment P0 $(4.74 \%)$ and the lowest was in treatment P2 (3.93\%). This shows that the administration of sakura block does not affect the quality of milk, especially the fat content of milk because there is a negative result. The P0 treatment without Sakura block showed the highest fat content, proving that fat content was influenced by forage consumption. Milk fat content is influenced by the crude fiber content in the ration. If the crude fiber content is low, it can reduce the fat content of the milk produced (Sudono, 1999).

Milk protein is formed from three main sources derived from the blood, namely peptides, plasma proteins, and free amino acids. The increase in milk protein content was caused by a decrease in the forage ratio in the feed which caused the concentrate ratio to increase, this was seen from the low ratio of $\mathrm{BK}$ consumption at $\mathrm{P} 1$ and $\mathrm{P} 2$ and high consumption of BK P3 and P4. The increase in concentration levels resulted in an increase in metabolized energy or energy metabolism (ME) and crude protein in cattle feed grass and beer dregs (Sanh et al., 2002). Milk protein levels are relatively constant during lactation because these proteins are synthesized in the epithelial cells of the udder gland which are controlled by genes, namely DNA.

Milk Protein was the highest in treatment $\mathrm{P} 3$, at $5.12 \%$ and the lowest in treatment $\mathrm{P} 1,4.35$ percent. These results suggest giving sakura the blocks has a positive impact, however, the analysis of the variants still shows results not significantly different $(\mathrm{P}>0.05)$. This was in accordance with the results of the study Sulistyowati and Edward (2009), states that the treatment Blocks the Ark with no Block the Ark of the effect was not significant $(\mathrm{P}>0.05)$ on milk fat and milk protein.

Mc Donald et al. (2002) expressed increased levels of the protein in the milk depends on the intake of protein in livestock feed that forms amino acids and is absorbed by the body through the blood. The content of milk protein was positively correlated to the energy of the feed, especially carbohydrates that are soluble. Its availability facilitates the formation of propionate thus lowering the requirement of amino acids for gluconeogenesis that make the amino acids more available in the small intestine and protein synthesis in the mammary gland (Sukarni 2006).

\section{CONCLUSION}

The results showed that the administration of Sakura Blok (300-900 gr) in lactating FH cows had no effect on milk production and quality. However, the results showed that the fat content and protein content had met the quality standard of lactating FH cow's milk according to SNI 2011. The administration of Sakura block was good enough to produce milk quality and was highly favored by livestock, however, it is better to use cows that are not in the late period of lactation for optimal results. 


\section{REFERENCES}

Badan Standarisasi Nasional. 2011. Standar nasional Indonesia susu segar. Bagian 1Sapi SNI- 3141.1-2011. Badan Standardisasi Nasional. Jakarta.

Ball, P.J.H. and A.R. Peters. 2004. Reproduction in Cattle. 3rd Ed., Blackwell Publishing. Oxford, UK. Pp. 1-12, 40-55, 68-75, 79-91, 215-237.

Devendra, C. dan W. Burn.1994 Produksi Kambing di Daerah Tropis.Penerbit ITB Bandung.

Dewayani, N. 2012. Hubungan Antara Produksi Dan Kualitas Susu Sapi Perah Dengan Faktor Yang Mempengaruhi (Studi Kasus Di Pondok Ranggon, Jakarta Timur). Skripsi: Departemen Ilmu Produksi Dan Teknologi Peternakan Fakultas Peternakan Institut Pertanian Bogor.

Ensminger, M. E \&, D. T. Howard. 2006. Dairy Cattle Science. 4th Ed.The Interstate Printers and Publisher, Inc. Danville.

Jarmuji. 2000. Pengaruh pemberian suplementasi sakura blok terhadap bobot badan sapi, konsumsi, efisiensi pakan dan kecernaan pada kambing kacang. Skripsi Jurusan peternakan.Fakultas pertanian. Universitas Bengkulu. Bengkulu.

McDonald P, Edwards RA, Greenhalgh JFD, Morgan CA. 2002. Animal Nutrition. 6th Ed. London (GB). Pretice all.

Molento, C. 2008. Badan Standarisasi Nasional Typical lactation curve. Dept. Animal Science URL:http://AnimSci.AgrEnv.McGill. CA/involute/involute.htm. Tanggal akses 27 Oktober 2009.

Mukthar, A. 2006. Ilmu Produksi Ternak Perah. Surakarta: LPP dan UNS Prees.

Nugroho, A.T., P. Surjowardojo, M.N. Ihsan. 2010. Penampilan produksi sapi perah Friesian Holstein (FH) pada berbagai paritas dan bulan laktasi di ketinggian tempat yang berbeda. Jurnal Ilmu-Ilmu Peternakan. 20(1): 55-64.
[NRC] National Research Council. 1989. DairyCattle Requirement. 6th Revised Ed. National Academy Press. Washington, DC.

Rusman. A. 2015. Aplikasi konsentrat - PUFA yang Mengandung Curmiyeast Terhadap Produksi Susu Sapi Perah Fries Hollad. Skripsi. Jurusan peternakan Fakultas Pertanian. Universitas Bengkulu.

Sudono, A., R. F. Rsosdiana, Budi S. Setiawan, 2003. Beternak Sapi Perah Secara Intensif.Agro Media Pustaka. Jakarta.

Sudono, A.1999. Ilmu Produksi Ternak Perah. Diktat Kuliah Jurusan Ilmu Produksi Ternak. Fakultas Peternakan, Bogor Institut Pertanian Bogor. Bogor.

Sanh M.V., Wiktorsson H., \& Ly L.V. 2002.Effect of partial replacement of green grass by urea treated rice straw in winter on milk production of crossbred lactating cows.Asian-Aust J Anim Sci.

Santoso, U. 1999. Daya Simpan dan Uji Palatabilitas Sakura Block. Laporan Penelitian Universitas Bengkulu.

Sukarni. 2006. Produksi dan kualitas air susu kambing Peranakan Ettawa yang diberi tambahan urea molases blok dan atau dedak padi pada awal laktasi. J Animal Production. 1: 427-441.

Sulistyowati, E., U. Santoso, S. Mujiharjo dan S.A. Abutani. 2001. Produksisusu sapi potong laktasi dengan teknologi Tabut. Med. Pet. 24.(2) : 51-53. Ed. Khusus. Fapet IPB. Desember. ISSN:0126-0472.

Sulistyowati, E., U. Santoso, I. Badarina, E. Sutrisno, dan T. Saputra. 2008. Modification of temulawak (Curcuma xanthorrhiza, Roxb) levels of Tabut Blok on milk production of $\mathrm{FH}$ cows. Proceeding: Management Strategy of Animal Health and Production Control on Anticipation of Global Warming for Achievement of Millenium Development Goals. Veterinary Medicine, UNAIR and Fac. of Veterinary Medicine, UPM. Surabaya 3-4 June. Pp: 161-164. Fac. 
Sulistyowati, E., dan Erwanto. 2009. Produksi susu sapi perah FH laktasi yang Disuplementasi dengan beberapa. Level blok tabut. J. Indon. Trop. Anim. Agric. 34(2):81 - 87.

Sulistyowati, E., I, Badarina., dan S. Mujiharjo. 2018. Milk Production and Feed Efficiency of Dairy Cow Fed Concentrate Containing Durio zibethinus Peel Flour Fermented with Pleurotus ostreatus. ProceedingISAI $4^{\text {th }}$, August 28- 30, 2018. Bogor. Indonesia.

Yusran, H.A., A. Musofie dan K. Ma'sum, 1988. Evaluasi nilai ekomomi pemakaian Urea Molasis Blok dalam pakan ransum sapi perah. Prosiding Seminar Pengembangan Peternakan Pedesaan. Fakultas Peternakan, Universitas Jendral Soedirman, Purwokerto. 